
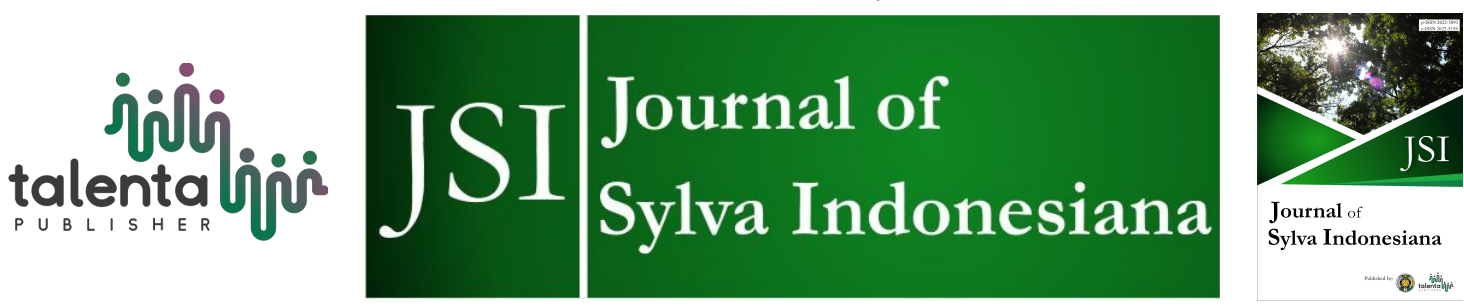

\title{
Editorial of The First Edition Journal of Sylva Indonesiana
}

\author{
Bejo Slamet ${ }^{1}$ and Arif Nuryawan ${ }^{2}$ \\ ${ }^{1}$ Department of Forest Management, Faculty of Forestry, Universitas Sumatera Utara, Medan, Indonesia \\ 20155 \\ ${ }^{2}$ Department of Forest Products Technology, Faculty of Forestry, Universitas Sumatera Utara, Medan, \\ Indonesia 20155
}

\begin{abstract}
This editorial is an opening remark of the first edition Journal of Sylva Indonesiana (JSI) containing the growth and development of the journal managed by Faculty of Forestry Universitas Sumatera Utara ("Fahutan USU"). In the first stage, "Jurnal Ilmiah Pertanian Kultura" published by Faculty of Agriculture USU has been targeted by faculty member of "Fahutan USU" for dissemination of their research results. This journal has been accredited by Directorate General of Higher Education in 2003 consequently its scope become specific, forestry science did not include therein. Hence, at that time, Program Study of Forestry Science under management of Faculty of Agriculture USU initiated the issuing of Peronema Forestry Science Journal in 2005 in order to accommodate scope of forestry science. Unfortunately the service and production of this journal become stagnant because most of the editorial staff pursued higher education in outside Medan city and the funding for publishing and printing vanished. In 2012, with the new spirit, Program of Forestry Science re-issued the new journal called "Foresta" Indonesian Journal of Forestry. It was a pity, the production process of this journal discontinued regarding to no submission of the manuscripts. All of the research results of undergraduate students of Program Study of Forestry Science have been uploaded into Peronema Forestry Science Journal in online version since 2014. In connection with establishment of organization structure of Faculty of Forestry completely, the publishing of JSI has been started in 2018 even though the editorial works of this journal has been begin since 2017, comprise call of paper, blind-review process, correspondence with the authors, layout and editing, including upload in the journal website. Supply of the manuscripts is provided not only from undergraduate research results of Faculty of Forestry's students but also from the outside. With the commitment of the funding from the Faculty of Forestry USU, hopefully JSI can reach the target as the national accredited journal and it can achieve the status to be a reputation journal in the field of forestry in the future.
\end{abstract}

Keyword: Dissemination, Editorial, Editorial Works, Journal of Sylva Indonesiana.

Received 4 December 2017 | Revised 11 December 2017 | Accepted 30 January 2018

\footnotetext{
*Corresponding author at: Universitas Sumatera Utara, Padang Bulan, Medan 20155, Indonesia

E-mail address: arif5@usu.ac.id
} 
The embryo of Forestry Faculty of USU has been formed around 1999-2001 with the establishment of Forest Management Study Program and Silviculture Study Program in 1999, followed by Forest Products Technology Study Program in 2001. The three study programs were previously under the management of the Forest Science Program. In 2004 they were transferred to be under the auspices of the Department of Forestry, Faculty of Agriculture, Universitas Sumatera Utara. Since then, the Faculty of Forestry has grown and developed, and undergone many changes such as institution management, governance and leadership, quality management and assurance systems, and also the issuance of forestry journals to disseminate lecturer research results.

The "Jurnal Ilmiah Pertanian" Kultura (ISSN 0126-1665), managed by the Faculty of Agriculture USU, was originally intended as a mean of publication for lecturers (Figure 1). We recorded several names who were active and successfully published their research in the journal; among them were Basyuni [1, 2], Muhdi [3] and Nuryawan [4]. At the end of 2003, the journal was accredited by Directorate General of Higher Education and recommended to narrow the scope to only publish agricultural articles. Therefore, the journal changed its name to Jurnal Ilmu Pertanian Kultivar and could no longer accept forestry manuscripts.

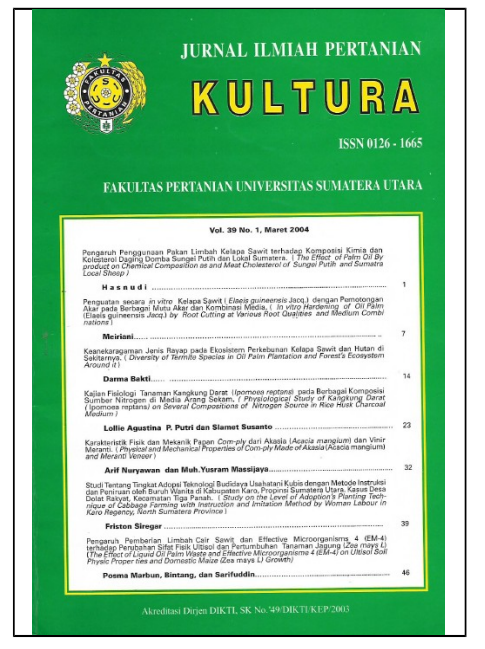

Figure 1 The front view of "Jurnal Ilmiah Pertanian" Kultura

On 2005, the management and publishing of forestry journals was initiated. The first Peronema Forestry Science Journal (ISSN 1829-6343) was published by self-funding. Due to the university's policy to print publications through USU Press, the first publication of the journal is reprinted and published consistently twice a year (Figure 2). Unfortunately, most of the editorial staffs had to study outside the city of Medan and the USU Press could no longer subsidize the publishing, so the printed journal was ended. There were four editions in total. 


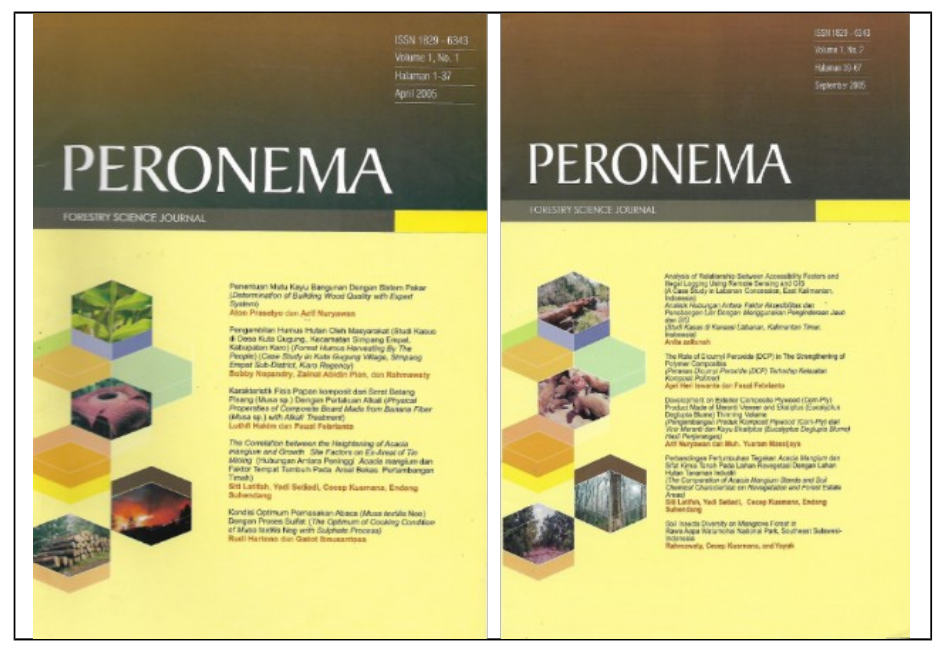

Figure 2 The front view of two Peronema Forestry Science Journals

The passion for continuing and reviving a professionally managed journal of forestry reemerged along with the return of the lecturers from their studies. The "Foresta" Indonesian Journal of Forestry (ISSN 2089-9890) was published on 2012, as shown on Figure 3. But this journal was also had to stop due to the editor's activities and the lack of article to be reviewed and published (personal communication).

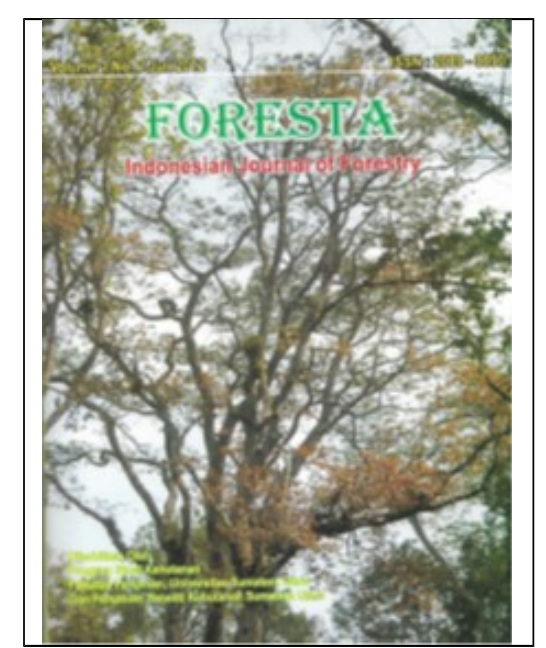

Figure 3 The front view of "Foresta" Indonesian Journal of Forestry

In line with Directorate General of Higher Education policy of requiring the research of undergraduate students to be periodically published, the dormant Peronema Forestry Science Journal revived its online version (https://jurnal.usu.ac.id/PFSJ) on 2014, as shown in Figure 4.

Based on internal evaluation, the online version of Peronema Forestry Science Journal has a weakness in terms of rigorous review as it demanded to immediate uploads in the journal page system as a student's graduation requirement. Furthermore, to meet the credit score of lecturer's research, many articles that have been uploaded in this journal were not recognized or approved 
as lecturer promotion materials. Therefore, it is necessary to publish periodically with standard review process (blind-review) so that its objectivity is maintained and meet the standard of journal articles in general.

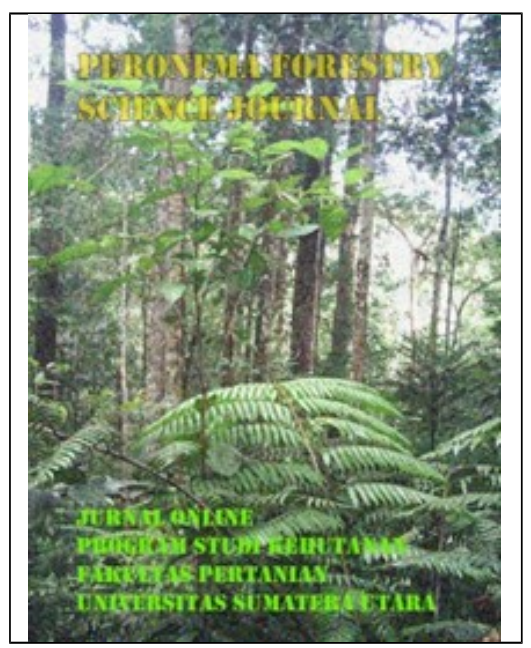

Figure 4 The online version of Peronema Forestry Science Journal

The Journal of Sylva Indonesiana (JSI) with p-ISSN 2622-5093 (printed) and e-ISSN 26225158 (electronic) is published in 2018 and embraces an anonymous or blind-review process. Manuscript availability is dominated by research result or thesis of forestry students which is more than $90 \%$. But unfortunately only $16 \%$ of them (15 manuscripts) are selected ones and willing to be review further. Being selected means willing to follow the JSI standard review process and approved by their supervisors. Those who are unwilling to be published on JSI generally considering other journals as it is part of a research grant won by their supervisors. The contribution of other manuscripts derived from agencies outside of the Faculty of Forestry Universitas Sumatera Utara including the research of lecturers from Faculty of Forestry (with no students) is still less than $6 \%$. The details of the manuscripts received by JSI's editorial for the full year of 2017 are presented in Table 1.

Table 1 The data of manuscripts received until the end of December 2017

\begin{tabular}{lccc}
\hline Manuscript's source & Published in SIJ & $\begin{array}{c}\text { Number of } \\
\text { manuscripts }\end{array}$ & Percentage (\%) \\
\hline $\begin{array}{l}\text { Result of research of } \\
\text { students of the Faculty of } \\
\text { Forestry USU }\end{array}$ & Willing & 15 & 12.71 \\
\cline { 2 - 4 } $\begin{array}{l}\text { Others (from other } \\
\text { agencies \& independent } \\
\text { lecturer research without } \\
\text { involving students) }\end{array}$ & Not willing & 96 & 81.36 \\
\cline { 2 - 4 } & Accepted & 6 & 5.08 \\
\hline Total & Rejected & 1 & 0.85 \\
\hline
\end{tabular}


The JSI editors would like to thank authors, who have been willing to entrust JSI in publishing their research results; reviewer partners who voluntarily and tirelessly review and provide suggestions and inputs to maintain the quality of articles on JSI, and the editors of previous journals in the Faculty of Forestry, Universitas Sumatera Utara, in particular:

1. Siti Latifah \& Arif Nuryawan as the Chairman and Deputy Chief Editor of Peronema Forestry Science Journal,

2. Mohammad Basyuni \& Luthfi Hakim as the Chairman and Deputy Chief Editor of "Foresta" Indonesian Journal of Forestry,

3. Yunus Afifuddin \& Edy Batara Mulya Siregar as Chairman and Deputy Chief Editor of Peronema Forestry Science Journal online version, which has shared the experience in journal management.

We would like to extend our gratitude and appreciation to the Dean of Forestry Faculty USU, who prioritized the issuance of JSI as a scientific communication media in the field of forestry, as well as the JSI Editorial Board, who are willing to maintain the quality of the manuscript in JSI publishing.

\section{REFERENCES}

[1] M. Basyuni, C. Kusmana, and U. J. Siregar, "Effect on the application seed tree method silvicultural system to the development of natural regeneration of mangrove forest in Riau," Jurnal Ilmiah Pertanian Kultura, vol. 37, no. 1, pp. 41-48, 2002.

[2] M. Basyuni, U. J. Siregar, and E. Sudarmonowati, "Correlation between phenotypic variation and isozyme marker in a Paraserianthesfalcataria in seed orchard Parung Panjang, Bogor," Jurnal Ilmiah Pertanian Kultura, vol. 36, no. 2, pp. 8-14, 2001.

[3] Muhdi, "Limbah pemanenan kayu akibat teknik pemanenan kayu di hutan alam tropika," Jurnal Ilmiah Pertanian Kultura, vol. 38, no. 2, pp. 83-88, 2003.

[4] A. Nuryawan, and M. Y. Massijaya, "Karakteristik fisik dan mekanik papan com-ply dari akasia (Acacia mangium) dan vinir meranti," Jurnal Ilmiah Pertanian Kultura, vol. 39, no. 1, pp. 32-38, 2004. 